\title{
THE RISE AND FALL OF MORAL CONFLICTS IN THE UNITED STATES AND CANADA
}

In The Rise and Fall of Moral Conflicts in the United States and Canada, sociologist Mildred A. Schwartz and political scientist Raymond Tatalovich bring their disciplinary insights to the study of moral issues. Beginning with prohibition, Schwartz and Tatalovich trace the phases of its evolution from emergence, establishment, decline and resurgence, to resolution. Prohibition's life history generates a series of hypotheses about how passage through each of the phases affected subsequent developments and how these were shaped by the political institutions and social character of the United States and Canada.

Using the history of prohibition in North America as a point of reference, the authors move on to address the anticipated progression and possible resolution of six contemporary moral issues: abortion, capital punishment, gun control, marijuana, pornography, and samesex relations. Schwartz and Tatalovich build a new theoretical approach by drawing from scholarship on agenda setting, mass media, social movements, and social problems. The Rise and Fall of Moral Conflicts in the United States and Canada provides new insights into how moral conflicts develop and interact with their social and political environment.

MILDRED A. SCHWARTZ is professor emerita in the Department of Sociology at the University of Illinois Chicago and visiting scholar, New York University.

RAYMond tatalovich is a professor in the Department of Political Science at Loyola University Chicago. 
This page intentionally left blank 


\section{The Rise and Fall of Moral Conflicts in the United States and Canada}

MILDRED A. SCHWARTZ AND

RAYMOND TATALOVICH

UNIVERSITY OF TORONTO PRESS

Toronto Buffalo London 
(C) University of Toronto Press 2018

Toronto Buffalo London

www.utorontopress.com

Printed in Canada

ISBN 978-1-4426-3726-9 (cloth) ISBN 978-1-4426-2883-0 (paper)

( ) Printed on acid-free, $100 \%$ post-consumer recycled paper with

vegetable-based inks.

\section{Library and Archives Canada Cataloguing in Publication}

Schwartz, Mildred A., 1932-, author

The rise and fall of moral conflicts in the United States

and Canada / Mildred A. Schwartz and Raymond Tatalovich.

Includes bibliographical references and index.

ISBN 978-1-4426-3726-9 (cloth). - ISBN 978-1-4426-2883-0 (paper)

1. Canada - Moral conditions - History - 20th century. 2. CanadaMoral conditions - History - 21st century. 3. United States - Moral conditions - History - 20th century. 4. United States - Moral conditions - History - 21st century. 5. Canada - Social conditions 20th century. 6. Canada-Social conditions - 21st century. 7. United States - Social conditions - 20th century. 8. United States - Social conditions - 21st century. I. Tatalovich, Raymond, author. II. Title. HN110.M6S33 $2018 \quad 306.0971 \quad$ C2017-906330-8

This book has been published with the help of a grant from the Federation for the Humanities and Social Sciences, through the Awards to Scholarly Publications Program, using funds provided by the Social Sciences and Humanities Research Council of Canada.

University of Toronto Press acknowledges the financial assistance to its publishing program of the Canada Council for the Arts and the Ontario Arts Council, an agency of the Government of Ontario.

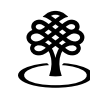

Canada Council for the Arts
Conseil des Arts du Canada

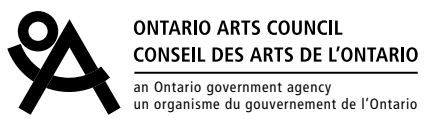

